\title{
A STUDY OF PLACE - NAMES OF RURAL SETTLEMENTS OF AMALNER OF JALGAON DISTRICT (MAHARASHTRA)
}

\author{
MAHAJAN MK \\ Assistant Professor, KES's Pratap College, Amalner (Autonomous), Dist. Jalgaon 425401 (MS) \\ *Corresponding Author: Dr. Mahendra K Mahajan: E Mail: mahendrakmahajan2930@gmail.com \\ Received $10^{\text {th }}$ June 2021; Revised $11^{\text {th }}$ July 2021; Accepted $20^{\text {th }}$ Aug. 2021; Available online $15^{\text {th }}$ Jan. 2022 \\ https://doi.org/10.31032/IJBPAS/2022/11.1.1002
}

\begin{abstract}
The study of place names is quite useful as it helps in identifying the influence of physical and cultural factors on the respective settlement. Perception of the most dominant aspect whether it may be physical or cultural of the place by the local inhabitants is reflected in the place name. In the present work, Amalner tehsil of Jalgaon district has been taken for the case study to better understand these phenomena. Here we found that cultural features have a more dominant influence than the physical aspects as most of the place names derived their origin from the cultural features. Physical features do not play a very significant role in influencing the names of villages in Amalner Tehsil.
\end{abstract}

Keywords: Place - settlement, physical and cultural factors, settlement place, landmarks \section{INTRODUCTION}

There is a famous quote from the play Romeo and Juliet written by William Shakespeare that what's in a name? That which we call a rose by any other name would smell as sweet. This quote may not be fully applicable to human beings but settlements having particular names give suggestions and hints about its origin their identifiable associations with physical and cultural characteristics of the region. (Chaudhari, 2018)

Settlement names are the basic source of information regarding the geographical features of that regions. The origin of the settlement name is a result of interaction between physical, cultural environment, and 
dialectal wealth of that region.

People, whether original inhabitants or subsequent settlers, perceive a place and its contents according to their cultural background and concretize the perceived reality by naming it according to their dialectal wealth. In course of time, the area may undergo a cultural transformation, but place names once transplanted, however, survive for a longer time, almost always and everywhere, than that of the cultural groups which created them (Anand, 1981)

The knowledge of local, regional language or a dialect is essential to find out the original meaning of the settlement place. Generally, settlement names bear prefix and suffix which shows the past association of the settlement and helps to know the physical and cultural situation in first hand. Settlement name provides clues to the early human habitats of the area. Brunhas (1920), rightly remarked that place names are as the fossils of Human Geography.

Here, is an attempt has been made to find out the associations of place names with their physical and cultural characteristics of a region of Amalner tehsil of Jalgaon district which is known as the largest tehsil of the region.

\section{STUDY AREA}

The study area, Amalner tehsil is one of the tehsils of Jalgaon district of Maharashtra state.
It lies in the western part of Jalgaon district between Latitudes $20056^{\prime} 36^{\prime \prime}$ to $21013^{\prime}$ '22', North and Longitudes 740 51' 27' to 750 24' 20' East. West flowing River Tapi borders the northern part and river Panjhara borders the western boundary of the tehsil. River Bori, one of the tributaries of Tapi, is a major Central flowing river of the region. Amalner, the head centre of the tehsil is situated on the western side of the river Bori. There are 152 villages in Amalner tehsil.

\section{OBJECTIVES}

- To study rural settlement names and their distribution in Amalner tehsil

- To analyse and categorise prefix and suffix of the rural settlement of Amalner tehsil

- To study the effect of physical and cultural aspects on settlement names of Amalner tehsil

\section{METHODOLOGY}

The present paper is based on secondary sources. The names of the rural settlement of Amalner tehsil have been obtained from the District Census Handbook (2011) and other relevant data also been taken from the District Census Handbook.

\section{DISCUSSION AND RESULT}

To understand the physical and cultural landmarks of the particular region, it is required to analyse the impact of these 
elements on the space of the region.

Settlements are good indicators of such impact which has high close relation with physical and cultural aspects. Settlement names have a good association with the physical and cultural characteristics of the region which serve as a basic source of information about the physical and cultural surrounding. When we investigate the place names, we come to know that these names are according to the local language or dialect, folklore, environment, cultural aspects. Hence, place names are classified into two broad groups.

\section{A. PLACE - NAMES RELATED TO NATURAL FEATURES}

The physical factors like land features, rocks, soils, vegetation and hydrological features are best reflected in a large number of places in Amalner region. Out of the total settlement, 58 names are related to these various natural features in Amalner tehsil.

Table No. 1.1

\begin{tabular}{|c|c|c|}
\hline Physical Features & No. of Villages & $\begin{array}{c}\text { \% of place- Names related to } \\
\text { features }\end{array}$ \\
\hline Land Features & 13 & 22.41 \\
\hline Hydrological Features & 11 & 18.97 \\
\hline Vegetation related Place Names & 24 & 41.38 \\
\hline Animals related Place Names & 10 & 17.24 \\
\hline Total & 58 & 100.00 \\
\hline
\end{tabular}

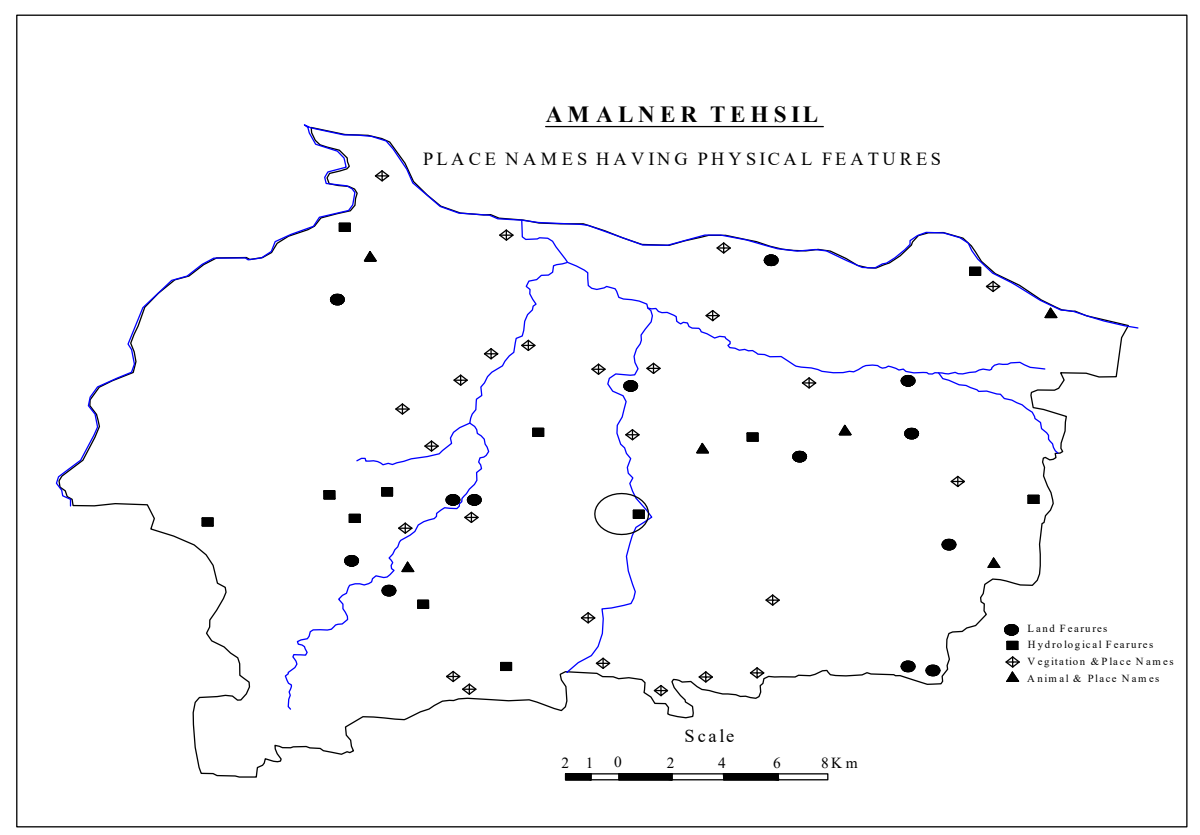

\subsection{Land features and place names}

The diversity of geographical aspects

of the region are reflected in place names. The
Fig. 1.1

character of the land is often signified by a suffix or a prefix in place names live Daregaon, Gadkham. Few settlement names 
show the nature of the slope like Nisardi.To show the erosional features the place names like Dhupi, Kharde, Kaushi etc have been used.

Some villages have names that contain a component to denote a rock. Such as Dodhawad, Khadke, Takarkhede etc.

There some villages have names related to the type of soils like Dheku BK, DhekuKh, Dheku Charam, Dheku Seem.

Out of the total number of villages in Amalner tehsil, only 13 villages have their names related to land features. This explains that land features do not play a significant role in influencing the names of villages. This may be due to the fact that from the point of view of the former inhabitants of the region land features were not that important.

\subsection{Hydralogical features and place - names}

Availability of water is the most important factor influencing the distribution of settlement in Amalner tehsil. The proportion of place names related to water features; therefore, is quite large. River Tapi boarders Amalner tehsil. The proportion of such place names is high in the piedmont plain of Tapi and Bori. The abundance of water has been reflected in place name like Amalner, Dhar, Londhave, Nalkheda etc. Nimzari, Shirsale,
Shirud, Talwade, Pilode, Ardi names are related to hydrological features like springs, wells, tanks etc.

Rice, the staple food of the people of the monsoon region, requires a good supply of water. The association of water and rice production is shown by place names like Tandali, Javakheda etc.

\subsection{Vegetation and Place Names}

It seems that the impact of vegetation on the place names is more pronounce than any of geographical features in the region. Places with names related to vegetation are distributed all over the region. The forest, found in the region, is chiefly of Tropical Dry Deciduous type, in which Wad, Bor, Pimple, Nim, Chinch, Amba, Babhul, Khair are more common. Ambare, Ambasan, Amode, Bhortek, Bohare, Borgaon, Dahiwad, Hingone, Indraprimpri, Kanhere, Kavprimpri, Marwad, Nim, Nimbhore, Palasdal, Pimpale, Pimpli, Radhavan, Sadavan, Sabagavan, Mathagavan, Zadi etc. are such examples of villages.

\subsection{Animals and Place Names}

Some villages in Amalner tehsil bear the names of animals like Mungase, Manjardi, Wasare, Vaghode, Mhasle, Gandhali belong to this category.

\section{B. PLACE NAMES RELATED TO}

CULTURAL FEATURES 
Place names are suggestive of cultural heritage, cultural diffusing and cultural borrowings. As such, they help in reconstructing a chronicle of the settlement process and the associated cultures and thereby facilitate an analysis of the Cultural Geography of an area (Anand, 1981). In Amalner tehsil, about $57.23 \%$ of place names are related to different aspects of prevalent culture. The place names underline the evidence of the prevalence and effective functioning of the Hindu culture. Place names have an impact on culture, society, religion, personal and political phenomena.

\subsection{Deities and Place Names}

Villages within the region under study are named after almost all the Hindu deities. Chopdai, Deogaon, Devali, Nandgaon, Rameshwar, Ranaiche are some examples where place - names are associated with names of various Hindu gods. Jaitpir, Shahapur are some of the examples which show the influence of Islam.

Table No. 1.2

\begin{tabular}{|c|c|c|}
\hline Cultural Features & No. of Villages & \% of place- Names related to features \\
\hline Place names related to Deities & 7 & 8.05 \\
\hline Place names related to Person's, chiefs or Kings & 7 & $\mathbf{8 . 0 5}$ \\
\hline Settlement characteristics related place names & 20 & 22.99 \\
\hline Human Characteristics related Place names & 53 & $\mathbf{6 0 . 9 2}$ \\
\hline Total & 87 & 100 \\
\hline
\end{tabular}

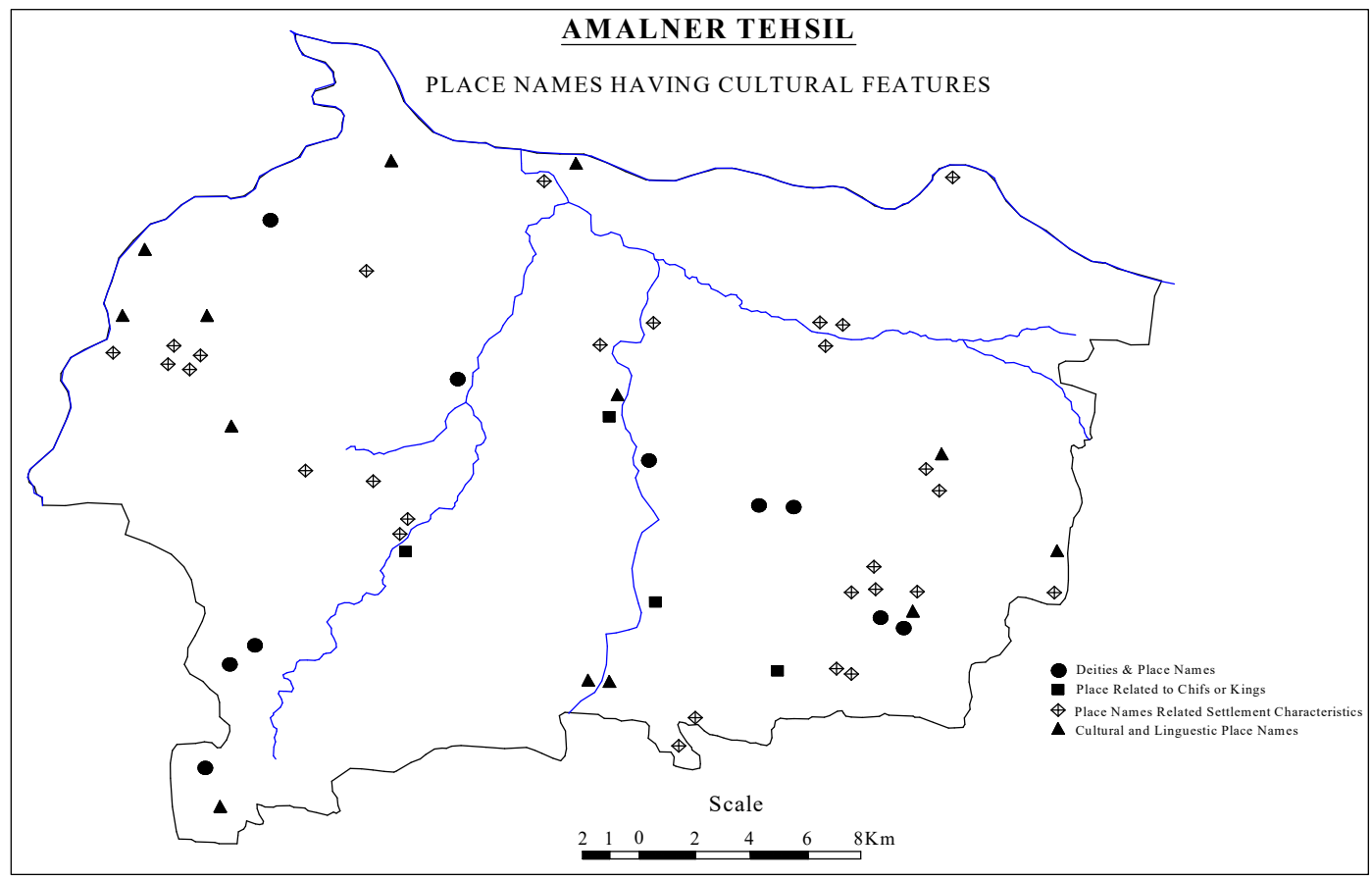

Fig. No. 1.2 


\subsection{Place names related to Chiefs or Kings}

Place names like Ranjane, Rajore, Chimanpuri, Shahpur, Bahadarwadi, Kamatwadi indicate their association with kings or chiefs.

\subsection{Settlement Characteristics and Place} Names

About 20 villages indicate characteristics of Digar show the hierarchy of villages based on settlement through words like pur, puri, kheda, khedi, wade, wadi, gaon, thane such as Amalgaon, Anchalwadi, Bahadarwadi, Galwade, Gangapuri, Ghurkheda, Kamatwadi, Karankheda, Khedi, Pingalwade, Savarkheda, Sonkhedi etc.

The suffixes like Nagar, Budruk, Khura, population size from big to small size villages.

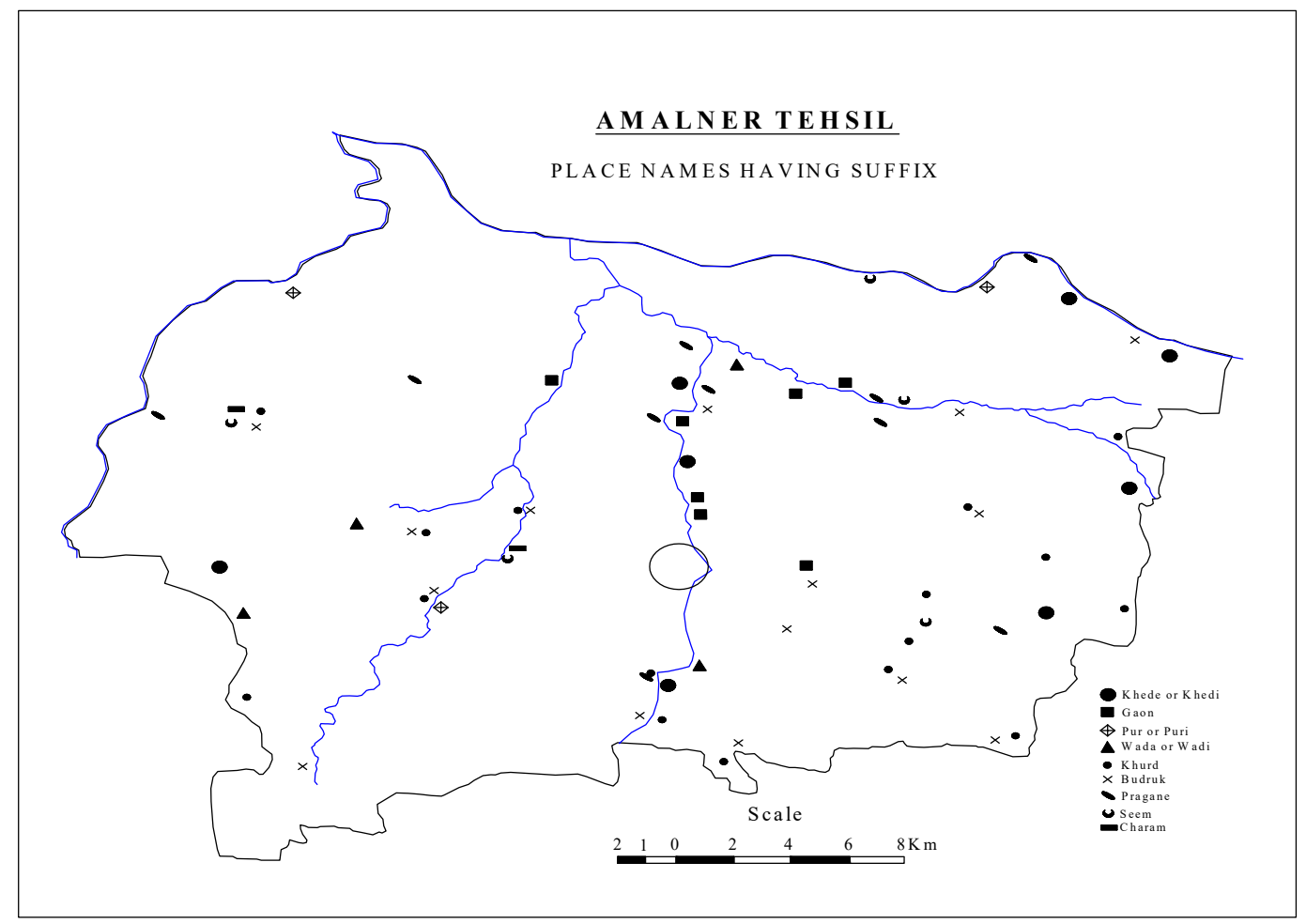

Fig. No. 1.3

Khurd and Budruk are found close to each other bear the same name. The suffix Budruk have originated as a result of diffusion from villages having suffix Khurd. Both carrying the same toponyms.

Budruk denotes an older and bigger village while Khurd denotes the newer and smaller settlement. There are many such pairs in the region. e. g. Dapori Bk and DaporiKh,
Fapore Bk and Faporekh, Khedi Bk and Khedikh, Pimpale Bk and PimpaleKh etc.

\subsection{Human Characteristics and Place} Names

About 53 villages have names that denote some human characteristics taking the largest share in cultural features (About 34.87\% in total per cent).

Among these names, human 
characteristics are found in significant number like Sundarpatti, Ladgaon, Eklahare, Ekrukhi, Ektas, Nagaon, Nadri etc.

Villages have names like Bamhane, Bhiladi, Bhilkheda, Mangloor show their association with different communities living in them.

Since agriculture has been the main occupation of the people of this tehsil there are several place names are related to crop, agriculture such as Tandali, Javkheda, Danore, Vavade, Dangri, Dangar etc.

The herdsmen came from Gujarat with their cattle in an adjoining part of Maharashtra which is presently known as Khandesh and settled here. Therefore, many villages in Khandesh have place names related to grazing, milk and milk products. In Amalner tehsil sabagawan, Mathagawan (the suffix 'gavan' means grazing land), Dahiwad, Lon, Loncharam, Lon are such examples.

Places like Khaparkheda, Khokarpat, Janave have names related to household articles. These household articles might have been prepared in these places.

It is observed that certain villages in Amalner tehsil have derived their names from identified above. Such names are categorised as miscellaneous such as Anora, some mathematical figures or Geometrical forms. For instant places like Ekrukhi, Eklahare, Ektas, Chaupale, Chaubari, Chakave, Atale, Lon - Pancham, Mandal, Pantonda (Five entrance), Satri etc belong to this category.

\subsection{Languages and Place Names}

Khandesh is most inhabited by herdsmen from Gujarat and known as Ahir and their dialect was Ahirani. Therefore, most of the place names are associated with Ahirani dialects. This region was under Muslim rule for many decades hence, few place names have origin in Urdu and as it is known that Sanskrit is considered as the Mother of all the languages has, directly and indirectly, influence in place names. Place names like Anturli, Bharvas, Bodarde, Junore, Kachare, Kalali, Kalambe, Kalamsare, Kandari, Kondaval, Kurhe, Sarbete, Mudi, Vyavhardale show their association with languages like Marathi, Hindi, Sanskrit and local Ahirani dialect.

C. PLACE NAMES RELATED TO MISCELLANEOUS

About 7 of the place names could not be put in any categories Hedave, Dapori etc. 


\begin{tabular}{|c|c|c|}
\hline \multicolumn{2}{|c|}{ Table No. 1.3 } & \% of place- Names related to features \\
\hline Features & No. of Villages & 8.55 \\
\hline Land Features & 13 & 7.24 \\
\hline Hydrological Features & 11 & 15.79 \\
\hline Vegetation related Place Names & 24 & 6.58 \\
\hline Animals related Place Names & 10 & 13.16 \\
\hline Settlement characteristics related place names & 20 & 4.61 \\
\hline Place names related to Deitied & 7 & 4.61 \\
\hline Place names related to Person's, chiefs or Kings & 7 & 34.87 \\
\hline Human Characteristics related Place names & 53 & 4.61 \\
\hline Miscellaneous & 7 & 100.00 \\
\hline
\end{tabular}

\section{CONCLUSIONS}

While studying the settlement names of Amalner tehsil of Jalgaon District, it is found that settlements have the influence of the physical and cultural environment. By the settlement names, we come to know about the evolution and history of the place. About $38 \%$ of place names have belonged to physical features and about $57 \%$ place names their origin in cultural features. While only $5 \%$ of place names are categorised as miscellaneous. It proves that cultural features in relation to place names are more dominant. Physical features do not play a very significant role in influencing the names of villages in Amalner tehsil.

\section{REFERENCES:}

[1] Chaudhari, Shankar R. (2018): Research Techniques and Applications in Rural Settlement Geography, Prashant publication, Jalgaon
[2] Anand, Sevita (1981):Place-names of Rural Settlements of the Outer Himalaya, A cultural Geographical Interpretations Transactions, Institute of Indian Geographers, Vol. 3 pp. 53 - 63.

[3] Singh, R. B. (1965):Historical Geography: Place-names and settlement - A review of studies, The National Geographical Journal of India, Vol. XI, PP. $101-124$

[4] Singh, R. Y. (977):Place names as tools of reconstructing Evolution of Settlement in the Malwa region, India, The Geographical Journal of India, Vol XXIII part 394, p200

[5] Pastapure, B. N. and Avhad Balaji (2014): Geographical Analysis of place names of settlement in Asna Basin, Maharashtra Bhuloshastra Sanshodhan Patrika, Vol. XXXI, No. 2, pp 20-27 